\title{
Kinorhyncha from the Caribbean, with the description of two new species from Puerto Rico and Barbados
}

\author{
Cepeda Diego ${ }^{1,}{ }^{*}$, Pardos Fernando ${ }^{1}$, Sánchez Nuria ${ }^{1,2}$
}

\author{
${ }^{1}$ Departamento de Biodiversidad, Ecología y Evolución, Facultad de Ciencias Biológicas, Universidad \\ Complutense de Madrid (UCM), José Antonio Novais St. 12, 28040, Madrid, Spain \\ 2 Laboratoire Environment Profond, Institut Français de Recherche pour l'Exploitation de la Mer \\ (IFREMER), Centre Bretagne - ZI de la Pointe du Diable, CS, 10070 - 29280, Plouzané, France \\ * Corresponding author : Diego Cepeda, email address : diegocepeda@ucm.es
}

\begin{abstract}
:
Two new kinorhynch species from Puerto Rico (Greater Antilles) and Barbados (Lesser Antilles) are described herein from Dr R. P. Higgins unexamined Caribbean meiofaunal samples, which have been stored in the Smithsonian Institution collections. The species from Puerto Rico, Cristaphyes cornifrons sp. nov., belongs to the class Allomalorhagida, whereas the species from Barbados, Echinoderes barbadensis sp. nov., belongs to the class Cyclorhagida. Cristaphyes cornifrons sp. nov. is easily distinguished from most of its congeners by the presence of lateral terminal spines and the absence of male, sexually dimorphic, ventromedial tubes on segment 2 , as only other two species of the genus lack these features. Of these, C. cornifrons sp. nov. may be easily differentiated by its pattern of paradorsal, ventrolateral and ventromedial setae. Echinoderes barbadensis sp. nov. is unique among its congeners by the combined presence of middorsal spines on segments 4-8, lateroventral spines on segments 6-9, lateral accessory tubes on segment 8 , lateroventral tubes on segment 5 , ventrolateral tubes on segment 2 and type 2 glandular cell outlets in subdorsal position on segment 2 and in midlateral position on segment 4.
\end{abstract}

Keywords : Kinorhynchs, biodiversity, meiofauna, morphology, taxonomy 
54

55

56

57

\section{Introduction}

Kinorhynchs, commonly known as mud dragons, are small, holobenthic, meiofaunal organisms that inhabit the spaces and crevices between the sediment particles of worldwide oceans (Neuhaus, 2013; Sørensen and Pardos, 2008). Much of the currently known biodiversity of the phylum includes intertidal to circalittoral species, biased by samplings being done in the most accessible marine areas (Neuhaus, 2013; Sørensen et al., 2018). However, many shoreline regions still remain poorly studied, as it is the case of the Caribbean Basin. The Caribbean is a tropical sea bounded by Mexico and Central America to the west and south west, by the Greater Antilles to the north, by the Lesser Antilles to the east and by the northern coast of South America to the south (Miloslavich et al., 2010). To date, a total of 30 species have been reported for the whole Basin (Higgins, 1983; Kirsteuer, 1964; Pardos et al. 2016b; Sørensen, 2006), but the study of several samples from different Caribbean localities stored at the Smithsonian National Museum of Natural History (NMNH) has revealed a still unknown, rich diversity of Caribbean kinorhynchs (Cepeda et al., this issue b, this issue c).

The present contribution is part of an extensive survey of Caribbean Kinorhyncha that take advantage of the series of samples deposited by Dr R. P. Higgins during several decades, samples that still remain unsorted and unexamined in the NMNH. Specifically, this paper focuses on Puerto Rico, part of the Greater Antilles, and Barbados, which is part of the Lesser Antilles, locations where the kinorhynch fauna is completely unknown. The present study describes two species new to science.

\section{Material and methods}

Studied kinorhynchs were collected by Dr R. P. Higgins at two different localities throughout the Caribbean Antilles (Fig. 1A): La Parguera (Puerto Rico) in 1967 (Fig. 1B) and St. James (Barbados) in 1968 (Fig. 1C). All the samplings were done using a meiobenthic dredge (Higgins, 1988).

After sampling, meiofauna was extracted from sediment using the bubble and blot method defined by Higgins (1964). Meiofaunal specimens were fixed in $4 \%$ formalin and finally preserved in Carosafe ${ }^{\circledR}$. Fixed kinorhynchs were picked up with an 
85 Irwin loop using a Motic $®$ SMZ-168 stereo zoom microscope and washed with distilled water to remove remnants of formalin. For light microscopy (LM), specimens were dehydrated though a series of $25 \%, 50 \%, 75 \%$ and $100 \%$ glycerine and mounted on glass slides using Fluoromount $G \AA$ sealed with Depex ${ }^{\circledR}$. Mounted specimens were studied and photographed using an Olympus® BX51-P microscope equipped with differential interference contrast (DIC) optics and an Olympus ${ }^{\circledR}$ DP-70 camera. Morphometrics were obtained with Olympus cellSens ${ }^{\circledR}$ software. For scanning electron microscopy (SEM), specimens were transferred to $70 \%$ ethanol and progressively dehydrated through a graded series of $80 \%, 90 \%, 95 \%$ and $100 \%$ ethanol. Hexamethyldisilazane (HMDS) was used for chemical drying through a HMDS-ethanol series. Specimens were finally coated with gold and mounted on aluminium stubs to be examined with a JSM® 6335-F JEOL SEM at the ICTS Centro Nacional de Microscopía Electrónica (Complutense University of Madrid, Spain). Type material is deposited at the NMNH, Smithsonian Institution, Washington, while non-type material is deposited at the Invertebrates Collection of the Meiofaunal Laboratory at the Universidad Complutense de Madrid (UCM), Spain. Line drawings and image plates composition were done using Adobe ${ }^{\circledR}$ Photoshop CC-2014 and Illustrator CC-2014 software.

\section{Results and discussion}

Class Allomalorhagida Sørensen et al., 2015

Family Pycnophyidae Zelinka, 1896

Genus Cristaphyes Sánchez et al., 2016

\subsection{Cristaphyes cornifrons sp. nov.}

urn:1sid:zoobank.org:act:5F5572D9-EB13-4205-8706-6D3BC6413DC3.

(Figs. 2-5 and Tables 2-3)

\subsubsection{Type material}

Holotype, adult female, collected by Dr R. P. Higgins on 7 June 1967 at La Parguera,

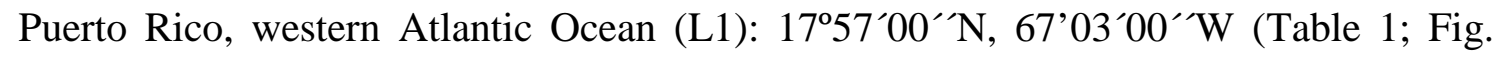
1A-B), $15 \mathrm{~m}$ depth, mud; mounted in Fluoromount $\mathrm{G}{ }^{\circledR}, \mathrm{NMNH}$ accession number: 
115 USNM 1550583. Two paratypes, one adult male and one adult female, with same

116 collecting data as holotype, mounted in Fluoromount G®, NMNH accession numbers:

117 USNM 1550584 and 1550585.

\subsubsection{Non-type material}

119 Two additional specimens with same collecting data as holotype and paratypes, 120 prepared for SEM, deposited at the Invertebrates Collection of the Meiofaunal 121 Laboratory of the Universidad Complutense de Madrid (UCM), Spain.

\subsubsection{Diagnosis}

123 Cristaphyes with middorsal processes on segments $2-9$, with small pointed projection of the tergal plate of segment 10. Anterior margin of first segment strongly denticulated, with "teeth" of different sizes. Unpaired paradorsal setae on segments 2, 4 and 6. Paired paralateral setae on segment 1; paired laterodorsal setae on segments 2-9; paired lateroventral setae on segments 2, 4, 6, 8 and 10; paired ventrolateral setae on segments 2, 3 (in some specimens mesially shifted to ventromedial position on segment 3 ) and 5 (females furthermore with sexually dimorphic, ventrolateral setae on segment 10); paired ventromedial setae on segments 4-9. Lateral terminal spines long, about $34 \%$ of total trunk length.

\subsubsection{Etymology}

From the latin "cornifrons", which refers to the lateral anterior horn-shaped extensions of segment 1 that are markedly elongated, curved and pointed.

\subsubsection{Description}

See Table 2 for measurements and dimensions, and Table 3 for summary of cuticular process, seta, glandular cell outlet, nephridiopore, spine and sensory spot locations.

Head with retractable mouth cone and introvert (Fig. 3C-D). Although two of the examined specimens had the introvert completely everted, oral styles and scalids tended to be collapsed when mounted for LM (Fig. 3C-D), so only some details can be provided. External ring of mouth cone (ring 00) with nine equally-sized outer oral styles

142 (Fig. 3C), arranged as one anterior to each introvert sector except for the middorsal sector 6 where a style is missing. Each outer oral style composed of a single, very flexible, superficially smooth piece with a basal, short, fringed sheath (Fig. 3C). Ring 
14501 with ten primary spinoscalids, each one composed of a basal sheath and a distal, 146 elongated piece; basal sheath equipped with a median, dense fringe (Fig. 3D). 147 Remaining rings of introvert (rings 02-06) with regular scalids morphologically similar 148 to the primary spinoscalids but shorter (Fig. 3D). Neck with four dorsal and two ventral, sclerotized placids (Figs. 2A-B and 3E150 F). Dorsal placids rectangular; mesial ones broader than lateral ones (Figs. 2B and 3E).

151 Ventral placids much more elongated and trapezoidal, getting thinner towards the lateral sides (Figs. 2A and 3F). Fourteen elongated, hairy trichoscalids are present, without trichoscalid plates (Fig. 3D).

Trunk markedly rectangular, stout, triangular in cross-section, composed of eleven segments (Figs. 2A-B, 3A-B and 5A-B). Segment 1 with one tergal, two episternal and one trapezoidal, midsternal plate; remaining segments with one tergal and two sternal plates (Figs. 2A-B, 3A-B and 5A-B). Midsternal and tergosternal junctions as conspicuous lines externally on the cuticle (Fig. 2A, C). Sternal plates reach their maximum width at segment 5 , but almost constant in width throughout the trunk, slightly tapering at the posterior trunk end (Figs. 2A-B, 3A-B and 5A-B). Sternal plates are relatively narrow (MSW-5:TL average ratio $=23.6 \%$ ), giving the animal a slender appearance. Middorsal processes on segments 2-9, keel-shaped, with pointed tips that surpass the posterior segment margins, turning progressively longer towards the posterior end (Figs. 2B, D, 3A, 4C-D, F, I and 5A, C-D); segment 10 with a small pointed projection towards the posterior segment margin (Figs. 2B, D and 4C). Segments 1-10 with oval-shaped glandular cell outlets in subdorsal and ventromedial position (Figs. 2A-D, and 4A-J). Segments 2-10 with paired cuticular ridges in laterodorsal position, not always detectable, followed by one small glandular cell outlet; segments 2-10 furthermore with paired cuticular ridges at the ventrolateralventromedial limit, followed by small glandular cell outlets with two cuticular openings (Figs. 2A-D and 5G). Cuticular hairs acicular, distributed all over the trunk cuticle, except the mesial halves of the episternal plates. Muscular scars very conspicuous as superficially smooth, hairless, rounded to oval-shaped areas on the cuticle, in laterodorsal and ventromedial positions (Figs. 2A-D and 4A-J). Pachycycli and balland-socket joints on segments 2-10 (Fig. 2A-B). Apodemes not observed. Posterior margin of segments straight, showing poorly-developed primary pectinate fringes with a very weak serration (Fig. 2A-D). Secondary pectinate fringes developed as three 
transverse, wavy rows with a very weak dentation, two of them located near the anterior margin of segments, one of them located near the posterior margin of segments (Fig. 2A-D). Some specimens were found carrying epibiontic Ciliophora on both tergal and sternal plates throughout the trunk.

Segment 1 without middorsal process (Figs. 2B and 4A). Anterolateral margins of the tergal plate large, elongated as horn-shaped extensions, curved inwards, distally pointed (Figs. 2A-B, 3A-B, F, 4B and 5A-B). Anterior margin of the tergal plate strongly denticulated, with projections of different sizes, followed by a smooth area (Figs. 2B, 3A and 5A). Paired setae in paralateral position (Figs. 2B and 4A). Paired sensory spots in subdorsal position, posterior to the dorsal cuticular scars; in laterodorsal position, lateral to the dorsal cuticular scars; and in ventrolateral position, lateral to the ventral muscular scars (Figs. 2A-B and 4A-B). Sensory spots on this and remaining segments rounded to oval, with several rings of cuticular papillae surrounding a central pore (similar to Fig. 5F, I).

Segment 2 with keel-like middorsal process that surpasses the posterior segment margin, with a median, densely-covered fringe of cuticular hairs (Figs. 2B, 4D and 5D). Unpaired seta in paradorsal position, and paired setae in laterodorsal, lateroventral and ventrolateral positions, the former immediately lateral to the dorsal muscular scars (Figs. 2A-B, 4D-E and 5D-E). Two pairs of sensory spots in subdorsal and ventromedial positions, the latter lateral to the ventral muscular scars; plus one pair of sensory spots in paradorsal and laterodorsal positions, the latter lateral to the laterodorsal setae (Figs. 2A-B, 4D-E and 5D-E). Sexually dimorphic male tubes absent.

Segment 3 with middorsal process as on preceding segment (Figs. 2B, 4F and 5D). Paired setae in laterodorsal and ventrolateral positions (Figs. 2A-B, 4F-G and 5D, F), the latter showing intraspecific variation as one of the examined specimens had this pair of setae mesially shifted to ventromedial position (Fig. 5E). Paired sensory spots in paradorsal, subdorsal, laterodorsal and ventromedial positions (Figs. 2A-B, 4F-G and 5D-F).

Segment 4 with middorsal process as on the preceding segment (Figs. 2B and 4I). Unpaired seta in paradorsal position, plus paired setae in laterodorsal, lateroventral and ventromedial positions (Figs. 2A-B and 4I-J). Paired sensory spotrs in paradorsal, subdorsal, laterodorsal and ventromedial positions (Figs. 2A-B and 4I-J). 
Segment 5 with tergal plate similar to that of segment 3 and sternal plates similar to those of segment 4 but also with paired ventrolateral setae (Figs. 2A-B and 4I-J). to those of segment 4 (Figs. 2A-B, 4I-J and 5I). and 5C).

Segment 9 with tergal plate similar to that of segment 3, but with lateroventral nephridiopores present, and sternal plates similar to those of segment 4 (Figs. 2A-B and $4 \mathrm{C}, \mathrm{H})$.

Segment 10 with small pointed projection towards the posterior margin of the tergal plate (Figs. 2B, D and 4C). Paired setae in lateroventral position; females furthermore with sexually dimorphic, paired setae in ventrolateral position (Figs. 2A-D and $4 \mathrm{C}, \mathrm{H})$. Two pairs of sensory spots in laterodorsal position, plus one pair of sensory spots in paradorsal, subdorsal, ventrolateral and ventromedial positions (Figs. 2A-D, $4 \mathrm{C}, \mathrm{H}$ and $5 \mathrm{H})$.

Segment 11 with two pairs of type 3 sensory spots, one in subdorsal and one in laterodorsal position (Figs. 2B, D and 4C). Males with two pairs of stout, penile spines and genital pores surrounded by tuft of long hairs (Figs. 2A and 5H). Lateral terminal spines long (LTS:TL average ratio $=34.0 \%$ ), stout, wide, apparently flexible (Figs. 2AD, 3A-B and 5B).

\subsection{Remarks on diagnostic characters}

Of the 23 species currently belonging to Cristaphyes, the newly described species may be distinguished from eight of them by the possession of lateral terminal spines, as C. anomalus (Lang, 1953), C. belizensis (Higgins, 1983), C. harrisoni Pardos et al., 2016, C. panamensis Pardos et al., 2016 (in Pardos et al. 2016a), C. phyllotropis (Brown and Higgins, 1983), C. rabaulensis (Adrianov, 1999 in Adrianov and Malakhov, 1999), C. spinosus (Lang, 1949) and C. yushini (Adrianov, 1989) lack these structures. Additionally, males of $C$. cornifrons sp. nov. do not have ventral tubes on segment 2, whereas males of eleven of the remaining congeners do, namely $C$. abyssorum (Adrianov and Maiorova, 2015), C. arctous (Adrianov, 1999 in Adrianov 
241 and Malakhov, 1999), C. carinatus (Zelinka, 1928), C. chukchiensis (Higgins, 1991), C.

242 cristatus (Sánchez et al., 2013), C. cryopygus (Higgins and Kristensen, 1988), C.

243 dordaidelosensis Sørensen and Grzelak, 2018, C. furugelmi (Adrianov, 1999 in

244 Adrianov and Malakhov, 1999), C. glaurung Sørensen and Grzelak, 2018, C. odhneri

245 (Lang, 1949) and C. scatha Sørensen and Grzelak, 2018. Male specimens of C. nubilis

246 (Sánchez et al., 2014) are unknown, so this species cannot be assumed to lack these

247 tubes. Of the four remaining congeners, C. chilensis (Lang, 1953) and C. nubilis possess

248 middorsal processes from segment 1, unlike $C$. cornifrons sp. nov. that has these

249 structures from segment 2. Moreover, both species differ from the new species by keel-

250 shaped middorsal process at segment 10 clearly surpassing beyond the posterior margin

251 of the segment (Lang, 1953; Sánchez et al., 2014).

252

253

254

255

256

257

258

259

260

261

262

263

264

265

266

267

268

269

270

271

272

273

Cristaphyes cornifrons sp. nov. is most similar to $C$. fortis Cepeda et al., this issue (in Cepeda et al., this issue a) and C. longicornis (Higgins, 1983) as all three of them share the presence of lateral terminal spines and the lack of ventral tubes on segment 2 in males. However, there are some remarkable differences in the setae arrangement, which justifies the erection of the new species: C. cornifrons sp. nov. possesses unpaired setae in paradorsal position on segments 2,4 and 6 , whereas $C$. longicornis carries these structures on segments 2, 4, 6 and 8. Additionally, $C$. cornifrons sp. nov. has paired setae in ventrolateral position on segments 2-3, 5 and 10 (only in females) and in ventromedial position on segments 4-9, while C. longicornis bears ventrolateral setae on segments 2,5 and 10 and in ventromedial position on segments 1 and 3-9. Main morphological differences in the setae location between $C$. cornifrons sp. nov. and C. fortis are found in the sternal plates. Thus, C. cornifrons sp. nov. is characterized by a single pair of ventrolateral setae on segments 2-3, 5 and 10 (only in females), while $C$. fortis has two pairs of ventrolateral setae on segment 5 and a single pair on segments 2-4, 6-7 and 10. Moreover, C. cornifrons sp. nov. has ventromedial setae on segments 4-9 whereas $C$. fortis bears these structures only on segments 8-9.

Additionally, Cristaphyes longicornis and $C$. fortis are larger species than $C$. cornifrons sp. nov. (TL average of $C$. cornifrons: $447.9 \mu \mathrm{m} ;$ C. fortis: $644.5 \mu \mathrm{m} ; C$. longicornis: $636.7 \mu \mathrm{m}$ ), and although the three species are characterized by having the anterolateral margins of segment 1 forming horn-shaped extensions, these are much more elongated and curved inwards in $C$. cornifrons sp. nov. than those of $C$. fortis and 
274 C. longicornis. Cristaphyes fortis also has the pachycycly and ball-and-socket joints

275 much more developed than $C$. cornifrons sp. nov, being thicker and stouter in the 276 former, but this could be related to the age of the type specimens of $C$. fortis. Finally, $C$.

277 longicornis possesses conspicuous apodemes in segments8-10, which are absent in $C$. 278 cornifrons sp. nov.

\section{$279 \quad$ 3.1.7 Associated kinorhynch fauna}

280 Cristaphyes cornifrons sp. nov. co-occurred with the cyclorhagids Echinoderes astridae

281

282
Class Cyclorhagida (Zelinka, 1896) Sørensen et al., 2015

Family Echinoderidae Zelinka, 1894

Genus Echinoderes Claparède, 1863

\subsection{Echinoderes barbadensis sp. nov.}

urn:1sid:zoobank.org:act:BCF2D1F5-A0AF-480E-B1E1-3E5AB93E1083.

(Figs. 6-8 and Tables 4-5)

\subsubsection{Type material}

Holotype, adult male, unknown collector, sampling done on 23 Aug 1968 at St. James (Barbados), Caribbean Sea, eastern Atlantic Ocean (L2): 13 ${ }^{\circ} 13^{\prime} 12^{\prime \prime} \mathrm{N}, 5^{\circ} 37^{\prime} 12^{\prime \prime} \mathrm{W}$ (Table 1; Fig. 1A, C), depth and sediment unknown; mounted in Fluoromount G®, NMNH accession number: USNM 1550576. Paratypes, three adult males and three adult females, with same collecting data as holotype; mounted in Fluoromount $\mathrm{B}$, NMNH accession numbers: USNM 1550577-1550582.

\subsubsection{Non-type material}

Six additional specimens with same collecting data as holotype and paratypes, mounted for SEM, deposited at the Invertebrates Collection of the Meiofaunal Laboratory at the Universidad Complutense de Madrid (UCM), Spain. 
302

303

304

305

306

307

308

309

310

311

312

313

314

315

316

317

318

319

320

321

322

323

324

325

326

327

328

329

330

331

332

\subsubsection{Diagnosis}

Echinoderes with short middorsal spines on segments 4-8, lateroventral spines on segments 6-9, lateral accessory tubes on segment 8, lateroventral tubes on segment 5 and ventrolateral tubes on segment 2. Type 2 glandular cell outlets present in subdorsal position on segment 2 and in midlateral position on segment 4. Cuticular hairs densely distributed through all cuticular surface (except on segment 11), very long, bracteate. Segment 11 with a middorsal, triangular, protuberance-like structure emerging between segments 10 and 11, located near the anterior segment margin. Sternal extensions of segment 11 bearing paired, very long, thick cuticular hairs.

\subsubsection{Etymology}

The species name refers to Barbados, the type locality where the species was found.

\subsubsection{Description}

See Table 4 for measurements and dimensions, and Table 5 for summary of spines, tubes, nephridiopores, glandular cell outlets and sensory spots location.

Head with retractable mouth cone and introvert. Although some of the paratypes have the introvert partially everted, oral styles and scalids tended to collapse when mounted for LM; furthermore, specimens for SEM were not suitable for head examination, so details on the exact number, arrangement and morphology of oral styles and scalids cannot be provided.

Neck with sixteen trapezoidal placids, wider at base, with a deep indentation on its anterior margin, and distinguished joint between the neck and segment 1 (Figs. 6A-B and 7B-C). Midventral placid widest (ca. 12-13 $\mu \mathrm{m}$ wide at base) (Figs. 6A and 7C), remaining ones alternate between wider and narrower (ca. 8-10 $\mu \mathrm{m}$ at base) (Figs. 6A-B and 7B-C). Placids situated closely together at base, distally separated by cuticular folds (Figs. 6A-B and 7B-C). Six long, hairy trichoscalids attached to trichoscalid plates present (Figs. 6A-B and 7B-C).

Trunk outline orbicular, stubby, strongly sclerotized, hairy, heart-shaped in cross-section, composed of eleven trunk segments (Figs. 6A-B, 7A and 8A). Segments 1-2 as closed cuticular rings; remaining ones with one tergal and two sternal plates (Figs. 6A-D and 7A). Midsternal and tergosternal junctions as conspicuous lines on the cuticle (Figs. 6A-D and 7A). Tergal anterior plates noticeably bulging middorsally; 
333 posterior ones more flattened, giving the animal a tapering outline in lateral view (Fig.

334 8A). Sternal plates reach their maximum width at segment 5, slightly tapering towards 335 the last trunk segments (Figs. 6A and 7A). Sternal plates conspicuously wide compared 336 to the total trunk length (MSW-5:TL average ratio $=25.9 \%$ ), giving the animal a 337 globose, stout appearance (Figs. 6A-B and 7A). Cuticular hairs densely distributed all 338 over the trunk cuticle, except on segment 11, in wavy, continuous, transversely arranged 339 rows along the surface of the cuticle (Figs. 6A-D, 7A-Q and 8A-C, E). Cuticular hairs 340 on all segments bracteate, long, slender, apparently flexible (Figs. 8A-E). Posterior margin of segments straight, with well-developed primary pectinate fringes with an elongated, strongly serrated free flap (Figs. 6A-D, 7A-Q and 8A, C); secondary pectinate fringes absent.

Segment 1 without spines and tubes. Unpaired type 1 glandular cell outlet in middorsal position, near the anterior segment margin; in LM, the glandular cells appear like a row of vertically arranged light refracting granules (Figs. 6B and 7D). Paired sensory spots in subdorsal, laterodorsal and ventrolateral positions, all of them located near the anterior segment margin (Figs. 6A-B and 7D-E). Sensory spots on this and remaining segments are small, circular to oval-shaped areas composed of a ring with few (ca. 8-10) micropapillae varying in size that surround a central pore with an emerging, quite long cilium, not flanked by cuticular hairs (similar to Fig. 8D, F). Cuticular hairs distributed in 7-9 rows (Figs. 6A-B and 7D-E).

Segment 2 with paired tubes in ventrolateral position (Figs. 6A and 7G). Type 1 glandular cell outlet unpaired in middorsal and paired in ventromedial positions, both located near the anterior segment margin, as rows of horizontally arranged light refracting granules (Figs. 6A-B and 7F-G). Paired type 2 glandular cell outlets in subdorsal position, (Figs. 6B, 7F and 8B). Paired sensory spots in laterodorsal position (Figs. 6B and 7F). Cuticular hairs distributed in 5-6 rows (Figs. 6A-B and 7F-G).

Segment 3 without spines and tubes. Type 1 glandular cell outlet unpaired in middorsal and paired in ventromedial positions, similar to those of preceding segments (Figs. 6A-B and 7H-I). Paired sensory spots in ventrolateral position (Figs. 6A and 7I). Cuticular hairs distributed as on the preceding segment. 
365

366

367

368

369

370

371

372

373

374

375

376

377

378

379

380

381

382

383

384

385

386

387

388

389

390

391

392

393

394

395

396

and ventromedial positions, similar to those of preceding segments (Figs. 6A-B and 7HI). Paired type 2 glandular cell outlets in midlateral position, near the posterior segment margin, smaller than those of the second trunk segment (Figs. 6A and 7I). Paired sensory spots in paradorsal and ventrolateral positions, the former anterior to the base of the middorsal spine, the latter near the posterior margin of segment (Figs. 6A-B and 7HI). Cuticular hairs distributed in 8-10 rows (Figs. 6A-B and 7H-I).

Segment 5 with a short, acicular middorsal spine not exceeding the posterior edge of the segment and paired tubes in lateroventral position (Figs. 6A-B, 7L-M and 8C). Paired type 1 glandular cell outlets in paradorsal and ventromedial positions, similar to those of preceding segments (Figs. 6A-B and 7L-M). Paired sensory spots in paradorsal, subdorsal and ventrolateral positions, the former anterior to the base of the middorsal spine, the latter near the posterior margin of segment (Figs. 6A-B and 7L-M). Cuticular hairs distributed in 7-10 rows (Figs. 6A-B and 7L-M).

Segment 6 with a short, middorsal spine not exceeding the posterior edge of the segment and paired spines in lateroventral position (Figs. 6A-B, 7L-M and 8C). Paired type 1 glandular cell outlets in paradorsal and ventromedial positions, similar to those of preceding segments (Figs. 6A-B and 7L-M). Paired sensory spots in paradorsal position, located anteriorly to the base of the middorsal spine (Figs. 6B and 7L). Cuticular hairs distributed in 7-9 rows (Figs. 6A-B and 7L-M).

Segment 7 similar to segment 6 but with the cuticular hairs distributed in 9-11 rows (Figs. 6A-B, 7J-K and $8 \mathrm{C}$ ).

Segment 8 with a middorsal spine not exceeding the posterior margin of the segment and paired spines in lateroventral position (Figs. 6A-B, 7J-K and 8C, E). Paired tubes in lateral accessory position (Figs. 6A, 7K and 8C, E). Paired type 1 glandular cell outlets in paradorsal and ventromedial positions, similar to those of preceding segments (Figs. 6A-B and 7J-K). Paired sensory spots in paradorsal, subdorsal and ventrolateral positions, the former anterior to the base of the middorsal spine, the latter close to the lateroventral spines near the anterior margin of segment (Figs. 6A-B, 7J-K and 8D). Cuticular hairs distributed in 9-12 rows (Figs. 6A-B and 7J-K).

Segment 9 with paired spines in lateroventral position (Figs. 6A, $7 \mathrm{O}$ and 8C). Cuticular hairs distributed in 10-13 wavy, continuous, transversely arranged rows along the surface of the cuticle (Figs. 6A-B and 7N-O). Paired type 1 glandular cell outlets in 
397 paradorsal and ventromedial positions, similar to those of preceding segments (Figs.

398 6A-B and 7N-O). Paired sensory spots in subdorsal and ventrolateral positions, the 399 latter close to the lateroventral spines, near the posterior margin of segment (Figs. 6A-B 400 and $7 \mathrm{~N}-\mathrm{O}$ ). Paired nephridiopores in sublateral position, as a longitudinally elongated, 401 oval-shaped sieve plate (Fig. 7O).

402 Segment 10 without spines and tubes. Two unpaired type 1 glandular cell outlets 403 in middorsal position, one horizontally arranged and near the anterior margin of 404 segment, the other one vertically arranged and posterior to the other outlet (Figs. 6B and 7P). Paired type 1 glandular cell outlets in ventromedial position, near the anterior margin of segment, obliquely arranged (Figs. 6A and 7Q). Paired sensory spots in

407

408

409

410

411

412

413

414

415

416

417

418

419

420 subdorsal position, not aligned with those of the previous segments, mesially shifted, near the posterior margin of segment (Figs. 6B and 7P). Cuticular hairs distributed in 10-12 rows (Figs. 6A-B and 7P-Q).

Segment 11 with quite short lateral terminal spines (LTS:TL average ratio = 20.1\%), stout, rigid, distally pointed, showing a central cavity (Fig. 6A-D and 7A, R). Females with paired lateral terminal accessory spines (LTAS:LTS average ratio = $34.7 \%$ ), slender, flexible, distally pointed (Fig. 6A-B). Males with three pairs of penile spines, first and third pairs longer and slender, superficially smooth and distally rounded, second pair shorter and stouter, superficially hairy with a distal tuft of hairs (Figs. 6C-D and 8G). Dorsal plate with an anterior, middorsal, triangular, protuberancelike structure that emerges between segments 10 and 11 (Fig. 6B, D). Unpaired type 1 glandular cell outlet in middorsal position, vertically arranged near the posterior margin of segment (Figs. 6B, D and 7P). Tergal extensions quite long, distally elongated and pointed (Figs. 6B, D and 7P). Sternal extensions wide, distally rounded, bearing a basal tuft of thick, long hairs (Figs. 6A, C, 7Q and 8G).

\subsubsection{Remarks on diagnostic characters}

Echinoderes barbadensis sp. nov. possesses middorsal spines on segments 4-8 and short, robust lateral terminal spines. There are only seven species with this pattern of characters: E. aquilonius Higgins and Kristensen, 1988, E. augustae Sørensen and Landers, 2014, E. brevicaudatus Higgins, 1966, E. cavernus Sørensen et al., 2000, E. lusitanicus Neves et al., 2016 (only females), E. obtuspinosus Sørensen et al., 2012 and E. ulsanensis Adrianov, 1999 in Adrianov and Malakhov, 1999. Nonetheless, E. 
429 barbadensis sp. nov. can be unambiguously distinguished from the aforementioned 430 congeners by the arrangement of the remaining spines and tubes, and the pattern of type 4312 glandular cell outlets.

432 Echinoderes lusitanicus and E. ulsanensis are the species that most differ from 433 E. barbadensis sp. nov., as only possess lateroventral spines on segments 8-9 and 6-8 434 respectively, whereas E. barbadensis has lateroventral spines on segments 6-9.

The pattern of tubes allows distinguishing E. aquilonius and E. obtuspinosus from E. barbadensis sp. nov: the first two bear these structures only in lateroventral position on segment 5, whereas the latter has tubes in lateral accessory position on segment 8, lateroventral position on segment 5 and ventrolateral position on segment 2 . The pattern of the type 2 glandular cell outlets is also different: E. aquilonius bears these structures in subdorsal position on segments 2 and 4, laterodorsal position on segment 10, sublateral position on segment 8 , midlateral position on segments 2 and 5, and ventrolateral position on segment $2 ;$ E. obtuspinosus has the glands in subdorsal position on segments 2 and 4, laterodorsal position on segment 2, sublateral position on segments 2 and 8, and ventrolateral position on segment 2; E. barbadensis sp. nov. only has type 2 glandular cell outlets in subdorsal position on segment 2 and midlateral position on segment 4.

Echinoderes augustae, E. brevicaudatus and E. cavernus are similar to E. barbadensis sp. nov. in the possession of lateroventral spines on segments 6-9, lateroventral tubes on segment 5 and lateroventral/ventrolateral tubes on segment 2 . However, E. augustae also possesses tubes in midlateral position on segment 4, laterodorsal position on segment 10 (only males), and sublateral position on segment 8, whereas E. barbadensis sp. nov. carries these structures only in lateral accessory position on segment 8. Additionally, E. brevicaudatus and E. cavernus lack tubes in lateral accessory position on segment 8 and type 2 glandular cell outlets, structures present in E. barbadensis sp. nov. as mentioned above.

\subsubsection{Associated kinorhynch fauna}

457 No other kinorhynch species co-occurred with E. barbadensis sp. nov. in the studied 458 location. 
460 ACKNOWLEDGEMENTS

461 We thank Dr Jon Norenburg and Katie Ahlfeld from the NMNH for loaning the studied 462 kinorhynch specimens.

463

\section{FUNDING SOURCES}

465 Cepeda was supported by a predoctoral fellowship of the Complutense University of 466 Madrid (CT27/16-CT28/16).

467 The authors declare no conflicts of interest.

468

\section{References}

470 Adrianov, A.V., 1989. The first report on Kinorhyncha of the Sea of Japan. Zool. Zh. $47168,17-27$.

472 Adrianov, A.V., Maiorova, A.S., 2015. Pycnophyes abyssorum sp. n. (Kinorhyncha:

473 Homalorhagida), the deepest kinorhynch species described so far. Deep Sea Res. Part 2

474 Top. Stud. Oceanogr. 111, 49-59. https://doi.org/10.1016/j.dsr2.2014.08.009.

475 Adrianov, A.V., Malakhov, V.V., 1999. Cephalorhyncha of the world ocean, first ed.

476 KMK Scientific Press, Moscow.

477 Brown, R., Higgins, R.P., 1983. A new species of Kinorhynchus (Homalorhagida, 478 Pycnophyidae) from Australia with a re-description and range extension of other 479 Kinorhyncha from the South Pacific. Zool. Scr. 12(3), 161-169. 480 https://doi.org/10.1111/j.1463-6409.1983.tb00561.x.

481 Cepeda, D., Álvarez-Castillo, L., Hermoso-Salazar, M., Sánchez, N., Gómez, S., 482 Pardos, F., 2019. Four new species of Kinorhyncha from the Gulf of California. Zool. 483 Anz., this issue a.

484 Cepeda, D., Pardos, F., Sánchez, N., 2019. A new species and first record of 485 Dracoderes (Kinorhyncha: Allomalorhagida: Dracoderidae) from American waters, 486 with a total-evidence phylogeny of the genus and an identification key. Zool. Anz., this 487 issue $b$. 
488 Cepeda, D., Sánchez, N., Pardos, F., 2019. First report of the family Zelinkaderidae 489 (Kinorhyncha: Cyclorhagida) for the Caribbean Sea, with the description of a new 490 species of Triodontoderes Sørensen and Rho, 2009 and an identification key for the 491 family. Zool. Anz., this issue c.

492 Claparède, A.R.E., 1863. Zur Kenntnis der Gattung Echinoderes Duj. Beobachtungen 493 über Anatomie und Entwicklungsgeschichte wirbelloser Thiere an der Küste von 494 Normandie angestellt, first ed. Verlag von Wilhelm Engelmann, Leipzig.

495 Higgins, R.P., 1964. Three new kinorhynchs from the North Carolina Coast. Bull. Mar. 496 Sci. 14, 479-493.

497 Higgins, R.P., 1966. Faunistic studies in the Red Sea (in winter, 1961-1962). Part II. 498 Kinorhynchs from the area of Al-Ghardaqa. Zool. Jahrb. Abt. Anat. Ontog. Tiere 93, $499 \quad 118-126$.

500 Higgins, R.P., 1983. The Atlantic barrier reef ecosystem at Carrie Bow Cay, Belize, II:

501 Kinorhyncha. Smithson. Contrib. Mar. Sci. 18, 1-131. 502 https://doi.org/10.5479/si.01960768.18.1.

503 Higgins, R.P., 1988. Kinorhyncha, in: Higgins, R.P.; Thiel, H. (Eds.), Introduction to 504 the study of meiofauna. Smithsonian Institution Press, Washington D.C., pp. 328-331.

505 Higgins, R.P., 1991. Pycnophyes chukchiensis, a new homalorhagid kinorhynch from 506 the Arctic Sea. Proc. Biol. Soc. Wash. 104(1), 184-188.

507 Higgins, R.P., Kristensen, R.M., 1988. Kinorhyncha from Disko Island, West 508 Greenland. Smithson. Contrib. Zool. 458, 1-56. 509 https://doi.org/10.5479/si.00810282.458.

510 Kirsteuer, E., 1964. Zur Kenntnis der Kinorhynchen Venezuelas. Zool. Anz. 173, 388511393.

512 Lang, K., 1949. Echinoderida. Further Zoological Results of the Swedish Antarctic 513 Expedition 1901-1903 4, 1-22.

514 Lang, K., 1953. Reports of the Lund University Chile Expedition 1948-1949. 9. 515 Echinoderida. Lunds Universitets Årsskrift N. F. Avd. 2 49(4), 3-8. 
516 Miloslavich, P., Díaz, J.M., Klein, E., Alvarado, J.J., Díaz, C., et al., 2010. Marine

517 biodiversity in the Caribbean: regional estimates and distribution patterns. PLoS ONE.

518 http://doi.org/10.1371/journal.pone.0011916.

519 Neuhaus, B., 2013. Kinorhyncha (=Echinodera), in: Schmidt-Rhaesa, A. (Ed.), 520 Handbook of Zoology, Gastrotricha, Cycloneuralia and Gnathifera, Volume 1:

521 Nematomorpha, Priapula, Kinorhyncha, Loricifera. De Gruyter, Hamburg, pp. 181-350.

522 Neves, R., Sørensen, M.V., Herranz, M., 2016. First account on kinorhynchs from 523 Portugal, with the description of two new species: Echinoderes lusitanicus sp. nov. and 524 E. reicherti sp. nov. Mar. Biol. Res. 12(5), 1-16. 525 https://doi.org/10.1080/17451000.2016.1154973.

526 Pardos, F., Herranz, M., Sánchez, N., 2016a. Two sides of a coin: the phylum 527 Kinorhyncha in Panama. II) Pacific Panama. Zool. Anz. 265, 26-47. 528 https://doi.org/10.1016/j.jcz.2016.06.006.

529 Pardos, F., Sánchez, N., Herranz, M., 2016b. Two sides of a coin: the phylum 530 Kinorhyncha in Panama. I) Caribbean Panama. Zool. Anz. 265, 3-25. 531 https://doi.org/10.1016/j.jcz.2016.06-005.

532 Sánchez, N., Pardos, F., Sørensen, M.V., 2014. Deep-sea Kinorhyncha: two new species 533 from the Guinea Basin, with evaluation of an unusual male feature. Org. Divers. Evol. 534 14(4), 349-361. https://doi.org/10.1007/s13127-014-0182-6.

535 Sánchez, N., Rho, M.S., Min, W.G., Kim, D., Sørensen, M.V., 2013. Four new species 536 of Pycnophyes (Kinorhyncha: Homalorhagida) from Korea and the East China Sea. Sci. 537 Mar. 77(2), 353-380. https://doi.org/10.1007/s13127-014-0182-6.

538 Sánchez, N., Yamasaki, H., Pardos, F., Sørensen, M.V., Martínez, A., 2016. 539 Morphology disentangles the systematics of a ubiquitous but elusive meiofaunal group 540 (Kinorhyncha: Pycnophyidae). Cladistics 32(5), 479-505. 541 https://doi.org/10.1111/cla.12143.

542 Sørensen, M.V., 2006. New kinorhynchs from Panama, with a discussion of some 543 phylogenetically significant cuticular structures. Meiofauna Marina 15, 51-77. 
544 Sørensen, M.V., 2014. First account of echinoderid kinorhynchs from Brazil, with the

545 description of three new species. Mar. Biodivers. 44, 251-274.

546 https://doi.org/10.1007/s12526-013-0181-4.

547 Sørensen, M.V., Dal Zotto, M., Rho, H.S., Herranz, M., Sánchez, N., Pardos, F.,

548 Yamasaki, H., 2015. Phylogeny of Kinorhyncha based on morphology and two

549 molecular loci. PLoS ONE 10(7), e0133440.

550 https://doi.org/10.1371/journal.pone.0133440.

551 Sørensen, M.V., Grzelak, K., 2018. New mud dragons from Svalbard: three new species

552 of Cristaphyes and the first Arctic species of Pycnophyes (Kinorhyncha:

553 Allomalorhagida: Pycnophyidae). PeerJ 6, e5653. https://doi.org/10.7717/peerj.5653.

554 Sørensen, M.V., Heiner, I., Ziemer, O., 2005. A new species of Echinoderes from

555 Florida (Kinorhyncha: Cyclorhagida). Biol. Soc. Wash. 118(3), 499-508.

556 https://doi.org/10.2988/0006-324X.

557 Sørensen, M.V., Jørgensen, A., Boesgaard, T.M., 2000. A new Echinoderes

558 (Kinorhyncha: Cyclorhagida) from a submarine cave in New South Wales, Australia.

559 Cah. Biol. Mar. 41, 167-179.

560 Sørensen, M.V., Landers, S.C., 2014. Two new species of Echinoderes (Kinorhyncha:

561 Cyclorhagida) from the Gulf of Mexico. Front. Mar. Sci. 1, e8.

562 https://doi.org/10.3389/fmars.2014.00008.

563 Sørensen, M.V., Pardos, F., 2008. Kinorhynch systematics and biology - An 564 introduction to the study of kinorhynchs, inclusive identification keys to the genera. 565 Meiofauna Marina 16, 21-73.

566 Sørensen, M.V., Rho, H.S., Min, W.G., Kim, D., Chang, C.Y., 2012. An exploration of 567 Echinoderes (Kinorhyncha: Cyclorhagida) in Korean and neighboring waters, with the 568 description of four new species and a redescription of E. tchefouensis Lou, 1934. 569 Zootaxa 3368, 161-196.

570 Zelinka, C., 1894. Über die Organisation von Echinoderes. Verh. Dtsch. Zool. Ges. 4, $57146-49$.

572 Zelinka, C., 1896. Demonstration der Tafeln der Echinoderes - Monographie. Verh. 573 Dtsch. Zool. Ges. 6, 197-199. 
574 Zelinka, C., 1928. Monographie der Echinodera, first ed. Engelmann Press, Leipzig.

575

576

577

578

579

580

581

582

583

584

585

586

587

588

589

590

591

592

593

594

595

596

597 


\section{TABLES}

599 Table 1. Data on sampling localities and habitat of the collected specimens.

\begin{tabular}{llllll}
\hline Station code & Location & $\begin{array}{c}\text { Geographical } \\
\text { coordinates }\end{array}$ & $\begin{array}{c}\text { Sampling } \\
\text { date }\end{array}$ & Sediment & Depth (m) \\
\hline L1 & La Parguera & $17^{\circ} 57^{\prime} 00^{\prime} \mathrm{N}$ & $07 / 06 / 1967$ & Mud & 15 \\
& (Puerto Rico) & $67^{\prime} 03^{\prime} 00^{\prime} \mathrm{W}$ & & & \\
L2 & St. James & $13^{\circ} 13^{\prime} 12^{\prime} \mathrm{N}$ & $23 / 08 / 1968$ & Unknown & Unknown \\
& (Barbados) & $59^{\circ} 37^{\prime} 12^{\prime} \mathrm{W}$ & & & \\
& & & & &
\end{tabular}

600

601 Table 2. Measurements of adult Cristaphyes cornifrons sp. nov. from Puerto Rico, 602 including number of measured specimens $(n)$, mean of data and standard deviation 603 (SD). Abbreviations: LTS, lateral terminal spine; MSW-5, maximum sternal width (on 604 segment 5); S, segment lengths (numbers after S indicate the corresponding segment); 605 SW-10, standard sternal width (on segment 10); TL, total length of trunk.

\begin{tabular}{lll}
\hline Character & Range & Mean $($ SD; $\boldsymbol{n})$ \\
\hline TL $(\mu \mathrm{m})$ & $422.6-481.8$ & $447.9(30.5 ; 3)$ \\
MSW-5 $(\mu \mathrm{m})$ & $101.0-111.7$ & $105.3(5.6 ; 3)$ \\
MSW-5/TL $(\%)$ & $21.5-24.0$ & $23.6(2.0 ; 3)$ \\
SW-10 $(\mu \mathrm{m})$ & $76.9-104.2$ & $88.1(14.3 ; 3)$ \\
SW-10/TL $(\%)$ & $16.0-23.7$ & $19.8(3.9 ; 3)$ \\
S1 $(\mu \mathrm{m})$ & $68.5-82.0$ & $76.2(7.0 ; 3)$ \\
S2 $(\mu \mathrm{m})$ & $35.1-40.6$ & $38.5(3.0 ; 3)$ \\
S3 $(\mu \mathrm{m})$ & $43.3-50.0$ & $46.0(3.3 ; 3)$ \\
S4 $(\mu \mathrm{m})$ & $44.7-49.8$ & $47.0(2.6 ; 3)$ \\
S5 $(\mu \mathrm{m})$ & $45.8-51.6$ & $48.9(2.9 ; 3)$ \\
S6 $(\mu \mathrm{m})$ & $48.3-53.5$ & $50.6(2.6 ; 3)$ \\
S7 $(\mu \mathrm{m})$ & $47.1-52.5$ & $48.9(3.1 ; 3)$ \\
S8 $(\mu \mathrm{m})$ & $47.8-54.5$ & $50.6(3.5 ; 3)$ \\
S9 $(\mu \mathrm{m})$ & $46.9-58.7$ & $53.4(6.0 ; 3)$ \\
S10 $(\mu \mathrm{m})$ & $35.5-49.0$ & $43.4(7.1 ; 3)$ \\
S11 $(\mu \mathrm{m})$ & $24.6-38.7$ & $29.6(7.8 ; 3)$ \\
LTS $(\mu \mathrm{m})$ & $111.7-181.8$ & $151.6(36.0 ; 3)$ \\
LTS/TL $(\%)$ & $25.4-43.0$ & $34.0(8.8 ; 3)$
\end{tabular}

607 Table 3. Summary of nature and arrangement of sensory spots, glandular cell outlets, cuticular processes, setae, nephridiopores and spines in adults of Cristaphyes cornifrons 
609 sp. nov. Abbreviations: cp, cuticular process; f, female condition of sexually dimorphic

610 character; gco, glandular cell outlet; LD, laterodorsal; lts, lateral terminal spine; LV,

611 lateroventral; m, male condition of sexually dimorphic character; MD, middorsal; ne,

612 nephridiopore; PD, paradorsal; PL, paralateral; ps, penile spine; se, seta; ss, sensory

613 spot; ss3, type 3 sensory spot; SD, subdorsal; VL, ventrolateral; VM, ventromedial; ${ }^{\wedge}$,

614 indicates intraspecific variation between ventrolateral or ventromedial position; *,

615 indicates unpaired structures.

\begin{tabular}{|c|c|c|c|c|c|c|c|}
\hline Segment & MD & PD & SD & LD & PL $\quad$ LV & VL & VM \\
\hline 1 & & & $\mathrm{gco}, \mathrm{ss}$ & SS & se & ss, gco & \\
\hline 2 & $\mathrm{cp}$ & $\mathrm{se}^{*}, \mathrm{ss}$ & gco, ss, ss & gco, se, ss & se & se, gco & ss, ss, gco \\
\hline 3 & $\mathrm{cp}$ & ss & $\mathrm{gco}, \mathrm{ss}$ & gco, se, ss & & $\mathrm{se}^{\boldsymbol{\Lambda}}, \mathrm{gco}$ & ss, gco \\
\hline 4 & $\mathrm{cp}$ & $\mathrm{se}^{*}, \mathrm{ss}$ & gco, ss & gco, se, ss & se & gco & ss, se, gco \\
\hline 5 & $\mathrm{cp}$ & ss & gco, ss & gco, se, ss & & se, gco & ss, se, gco \\
\hline 6 & $\mathrm{cp}$ & $\mathrm{se}^{*}, \mathrm{ss}$ & gco, ss & gco, se, ss & D & gco & ss, se, gco \\
\hline 7 & $\mathrm{cp}$ & ss & gco, ss & gco, se, ss & & gco & ss, se, gco \\
\hline 8 & $\mathrm{cp}$ & ss & gco, ss & gco, se, ss & se & gco & ss, se, gco \\
\hline 9 & $\mathrm{cp}$ & ss & gco, ss & gco, se, ss & ne & gco & ss, se, gco \\
\hline 10 & $\mathrm{cp}$ & ss & gco, ss & gco, ssx, ss & se & se (f), ss, gco & ss, gco \\
\hline 11 & & & ss3 & ss3 & lts, & & \\
\hline
\end{tabular}

616

617 Table 4. Measurements of adult Echinoderes barbadensis sp. nov. from Barbados, 618 including number of measured specimens $(n)$, mean of data and standard deviation 619 (SD). Abbreviations: ac, acicular spine; LA, lateral accessory; LTAS, lateral terminal 620 accessory spine; LTS, lateral terminal spine; LV, lateroventral; MD, middorsal; MSW621 5, maximum sternal width (on segment 5); S, segment lengths (numbers after S indicate 622 the corresponding segment); SW-10, standard sternal width (on segment 10); TL, total 623 length of trunk; tu, tube; VL, ventrolateral.

\begin{tabular}{lll}
\hline Character & Range & Mean $($ SD; $\boldsymbol{n})$ \\
\hline TL $(\mu \mathrm{m})$ & $223.7-307.0$ & $275.0(18.6 ; 20)$ \\
MSW-5 $(\mu \mathrm{m})$ & $62.5-86.6$ & $71.0(4.8 ; 20)$ \\
MSW-5/TL $(\%)$ & $23.2-32.1$ & $25.9(2.0 ; 20)$ \\
SW-10 $(\mu \mathrm{m})$ & $53.6-67.0$ & $59.2(4.1 ; 20)$ \\
SW-10/TL $(\%)$ & $20.0-24.5$ & $21.6(1.8 ; 20)$ \\
S1 $(\mu \mathrm{m})$ & $29.0-33.9$ & $31.1(1.3 ; 20$ \\
S2 $(\mu \mathrm{m})$ & $27.2-33.5$ & $30.1(1.7 ; 20)$
\end{tabular}




$\begin{array}{lll}\text { S3 }(\mu \mathrm{m}) & 29.7-35.9 & 32.9(1.7 ; 20) \\ \text { S4 }(\mu \mathrm{m}) & 26.5-40.4 & 36.8(2.9 ; 20) \\ \text { S5 }(\mu \mathrm{m}) & 31.8-42.1 & 37.1(2.3 ; 20) \\ \text { S6 }(\mu \mathrm{m}) & 32.6-42.7 & 38.8(2.4 ; 20) \\ \text { S7 }(\mu \mathrm{m}) & 37.1-42.6 & 40.5(1.4 ; 20) \\ \text { S8 }(\mu \mathrm{m}) & 40.3-44.3 & 42.4(1.4 ; 20) \\ \text { S9 }(\mu \mathrm{m}) & 39.4-46.9 & 44.2(1.8 ; 20) \\ \text { S10 }(\mu \mathrm{m}) & 41.1-48.7 & 45.8(1.8 ; 20) \\ \text { S11 }(\mu \mathrm{m}) & 22.3-39.2 & 31.7(3.9 ; 20) \\ \text { MD4 }(\mathrm{ac})(\mu \mathrm{m}) & 6.5-12.6 & 9.6(1.6 ; 18) \\ \text { MD5 }(\mathrm{ac})(\mu \mathrm{m}) & 6.8-12.2 & 9.7(1.4 ; 19) \\ \text { MD6 }(\mathrm{ac})(\mu \mathrm{m}) & 7.7-13.6 & 10.5(1.7 ; 19) \\ \text { MD7 }(\mathrm{ac})(\mu \mathrm{m}) & 6.7-14.8 & 11.0(2.1 ; 19) \\ \text { MD8 }(\mathrm{ac})(\mu \mathrm{m}) & 7.3-12.8 & 10.5(1.2 ; 20) \\ \text { VL2 }(\mathrm{tu})(\mu \mathrm{m}) & 6.3-11.5 & 8.6(1.4 ; 15) \\ \text { LV5 }(\mathrm{tu})(\mu \mathrm{m}) & 6.3-11.1 & 8.4(1.2 ; 19) \\ \text { LV6 }(\mathrm{ac})(\mu \mathrm{m}) & 8.0-13.6 & 11.0(1.4 ; 20) \\ \text { LV7 }(\mathrm{ac})(\mu \mathrm{m}) & 8.0-13.7 & 10.4(1.3 ; 20) \\ \text { LV8 }(\mathrm{ac})(\mu \mathrm{m}) & 9.1-15.0 & 10.6(1.4 ; 20) \\ \text { LA8 }(\mathrm{tu})(\mu \mathrm{m}) & 6.3-10.9 & 7.7(1.0 ; 20) \\ \text { LV9 }(\mathrm{ac})(\mu \mathrm{m}) & 9.5-13.4 & 11.3(1.3 ; 19) \\ \text { LTS }(\mu \mathrm{m}) & 48.4-58.3 & 55.1(2.5 ; 19) \\ \text { LTS/TL }(\%) & 17.4-24.9 & 20.1(1.9 ; 19) \\ \text { LTAS }(\mu \mathrm{m}) & 17.2-21.6 & 19.0(1.2 ; 10) \\ \text { LTAS/LTS }(\%) & 31.8-44.6 & 34.7(3.5 ; 10) \\ & & \end{array}$

624

625 Table 5. Summary of nature and arrangement of sensory spots, glandular cell outlets, 626 spines, tubes and nephridiopores in adults of Echinoderes barbadensis sp. nov. 627 Abbreviations: ac, acicular spine; f, female condition of sexually dimorphic character; 628 gco1/2, glandular cell outlet type 1/2; LA, lateral accessory; LD, laterodorsal; ltas, 629 lateral terminal accessory spine; lts, lateral terminal spine; LV, lateroventral; m, male 630 condition of sexually dimorphic character; MD, middorsal; ML, midlateral; ne, 631 nephridiopore; PD, paradorsal; pr, protuberance; ps, penile spine; SD, subdorsal; SL, 632 sublateral; ss, sensory spot; t, tube; VL, ventrolateral; VM, ventromedial.

\begin{tabular}{lllllllllll}
\hline Segment & MD & PD & SD & LD & ML & SL & LA & LV & VL & VM \\
\hline 1 & gco1 & & ss & ss & & & & & ss & \\
2 & gco 1 & & gco2 & ss & & & & & t & gco1
\end{tabular}




\section{ACCEPTED MANUSCRIPT}

\begin{tabular}{|c|c|c|c|c|c|c|}
\hline 3 & gco1 & & & & & ss \\
\hline 4 & $\mathrm{ac}$ & gco1, ss & & $\operatorname{gco} 2$ & & ss \\
\hline 5 & $\mathrm{ac}$ & gco1, ss & ss & & $\mathrm{t}$ & ss \\
\hline 6 & $\mathrm{ac}$ & gcol, ss & & & $\mathrm{ac}$ & \\
\hline 7 & $\mathrm{ac}$ & gcol, ss & & & $\mathrm{ac}$ & \\
\hline 8 & $\mathrm{ac}$ & gco1, ss & ss & & $\mathrm{ac}$ & ss \\
\hline 9 & & gco1 & ss & ne & $\mathrm{ac}$ & SS \\
\hline 10 & gco1, gco1 & & ss & & & \\
\hline 11 & pr, gcol & & & & lts & \\
\hline
\end{tabular}

633

634

635

636

637

638

639

640

641

642

643

644

645

646

647

648

649

650

651 
653 Fig. 1. General map (A) showing the sampling localities (B-C) through the Caribbean 654 Sea (western Atlantic Ocean).

655 Fig. 2. Line art illustrations of Cristaphyes cornifrons sp. nov. (A) Male, ventral 656 overview; (B) Male, dorsal overview; (C) Female, segments 10-11, ventral view; (D) 657 Female, segments 10-11, dorsal view. Abbreviations: dcr, dorsal cuticular ridge; dpl, 658 dorsal placid; gco, glandular cell outlet; ldgco, laterodorsal glandular cell outlet; ldms, 659 laterodorsal muscular scar; ldse, laterodorsal seta; ldss, laterodorsal sensory spot; ldss3, 660 laterodorsal type 3 sensory spot; lts, lateral terminal spine; lvse, lateroventral seta; 661 mdcp, middorsal cuticular process; pdse, paradorsal seta; pdss, paradorsal sensory spot; 662 plse, paralateral seta; ppf, primary pectinate fringe; ps, penile spine; S, segment 663 followed by number of corresponding segment; sdgco, subdorsal glandular cell outlet; 664 sdss, subdorsal sensory spot; sdss3, subdorsal type 3 sensory spot; spf, secondary pectinate fringes; vcr, ventral cuticular ridge; vlse, ventrolateral seta; vlss, ventrolateral sensory spot; vmgco, ventromedial glandular cell outlet; vmms, ventromedial muscular scar; vmse, ventromedial seta; vmss, ventromedial sensory spot; vpl, ventral placid.

Fig. 3. Light micrographs showing trunk overviews and details in the head and neck of female holotype USNM 1550583 (A-B) and male paratype USNM 1550585 (C-F) of Cristaphyes cornifrons sp. nov. (A) Dorsal overview of trunk; (B) ventral overview of trunk; (C) mouth cone, showing the outer oral styles (ring 00); (D) introvert, showing primary spinoscalids (ring 01), regular scalids and neck's trichoscalids (ring 07); (E) dorsal view of neck, showing the dorsal placids; (F) ventral view of neck, showing the ventral placids. Abbreviations: dpl, dorsal placid; lts, lateral terminal spines; oos, outer oral style; psc, primary spinoscalid; sc, scalid; ts, trichoscalid; vpl, ventral placid.

Fig. 4. Light micrographs showing trunk cuticular details of male paratype USNM 1550585 of Cristaphyes cornifrons sp. nov. (A) Left half of tergal plate of segment 1; (B) ventrolateral and ventromedial views on left half of segment 1; (C) left halves of tergal plates of segments 8-11; (D) left half of tergal plate of segment 2; (E) left sternal 680 plate of segment 2; (F) left half of tergal plate of segment 3; (G) left sternal plate of segment 3; $(\mathrm{H})$ lateroventral to ventromedial view on left sternal plates of segments 811; (I) left halves of tergal plates of segments 4-7; (J) left sternal plates of segments 4-7. 
684 lateroventral seta; mdcp, middorsal cuticular process; mdcpr, middorsal cuticular 685 projection; pdse, paradorsal seta; plse, paralateral seta; vlse, ventrolateral seta; vmse, 686 ventromedial seta; sensory spots are marked as closed circles, and glandular cell outlets 687 as dashed circles; numbers after abbreviations indicate the corresponding segment.

688 Fig. 5. Scanning electron micrographs showing general overviews and details of the 689 cuticular trunk morphology of non-type male of Cristaphyes cornifrons sp. nov. (A) 690 Lateral overview of trunk; (B) ventral overview of trunk; (C) paradorsal view on right 691 half of segment 8, with detail of the middorsal process and the paradorsal sensory spot; 692 (D) subdorsal to lateroventral view on right half of segments 2-3; (E) left sternal plates 693 of segments 2-3; (F) detail of ventrolateral seta and ventromedial sensory spot of 694 segment 3; (G) left sternal plates of segment 7, with detail of the ventral cuticular ridge 695 and the associated glandular cell outlets; (H) left sternal plates of segments 10-11, 696 showing the male penile spines; (I) ventromedial view on left half of segment 7, with 697 detail of the ventromedial seta and the ventromedial sensory spot. Abbreviations: ldse, 698 laterodorsal seta; lvse, lateroventral seta; ps, penile spine; vlse, ventrolateral seta; vmse, 699 ventromedial seta; sensory spots are marked as closed circles, and glandular cell outlets 700 as dashed circles; numbers after abbreviations indicate the corresponding segment.

701 Fig. 6. Line art illustrations of Echinoderes barbadensis sp. nov. (A) Female, ventral 702 overview; (B) Female, dorsal overview; (C) Male, segments 10-11, ventral view; (D) 703 Male, segments 10-11, dorsal view. Abbreviations: ch, cuticular tuft of hairs; dpl, dorsal placid; lat, lateral accessory tube; ldss, laterodorsal sensory spot; 1tas, lateral terminal accessory spine; lts, lateral terminal spine; lvs, lateroventral spine; lvt, lateroventral tube; mdgco1, middorsal type 1 glandular cell outlet; mdpb, middorsal protuberance; mds, middorsal spine; mlgco2, midlateral type 2 glandular cell outlet; mvp, midventral placid; ne, nephridiopore; pdgco1, paradorsal type 1 glandular cell outlet; pdss, paradorsal sensory spot; ppf, primary pectinate fringe; ps, penile spine; S, segment followed by number of corresponding segment; sdgco2, subdorsal type 2 glandular cell outlet; sdss, subdorsal sensory spot; te, tergal extension; tsp, trichoscalid plate; vlss, ventrolateral sensory spot; vmgco1, ventromedial type 1 glandular cell outlet; vlt, ventrolateral tube; cuticular hairs are drawn as grey dotes to make the interpretation of the remaining cuticular characters easier.

715 Fig. 7. Light micrographs showing overviews, neck and trunk cuticular details and structures of male holotype USNM 1550576 of Echinoderes barbadensis sp. nov. (A) 
717 Ventral overview of trunk; (B) dorsal view of neck, showing the dorsal placids; (C)

718 ventral view of neck, showing the ventral placids; (D) middorsal to laterodorsal view on

719 left half of segment 1; (E) lateroventral to ventromedial view on left half of segment 1;

720 (F) middorsal to laterodorsal view on left half of segment 2; (G) lateroventral to

721 ventromedial view on left half of segment 2; (H) left halves of tergal plates of segments

$7223-4$; (I) sublateral to ventromedial view on left half of segments $3-4$, (J) middorsal to

723 subdorsal view on left half of segments 7-8; (K) lateroventral to ventromedial view on

724 left half of segments 7-8; (L) middorsal to subdorsal view on left half of segments 5-6;

725 (M) lateroventral to ventromedial views on left half of segments 5-6; (N) middorsal to

726 subdorsal view on left half of segment 9; (O) lateroventral to ventromedial view on left

727 half of segment 9; (P) left halves of tergal plates of segments 10-11; (Q) left sternal

728 plates of segments 10-11; (R) lateral terminal spine. Abbreviations: lat, lateral accessory

729 tube; lvs, lateroventral spine; lvt, lateroventral tube; mds, middorsal spine; mvpl,

730 midventral placid; slne, sublateral nephridiopore; vlt, ventrolateral tube; sensory spots

731 are marked as closed circles, and glandular cell outlets as dashed circles; numbers after

732 abbreviations indicate the corresponding segment.

733 Fig. 8. Scanning electron micrographs showing general overview and details of the 734 cuticular trunk morphology of non-type female (A-B) and male (C-G) of Echinoderes 735 barbadensis sp. nov. (A) Lateral overview of trunk; (B) subdorsal to lateroventral view 736 on left half of segments 1-2; (C) lateroventral overview of segments 5-10; (D) detail of 737 ventrolateral sensory spot of segment 8; (E) detail of the lateral accessory tube and the 738 lateroventral spine of right side of tergal plate of segment 8; (F) detail of the 739 ventrolateral sensory spot of sternal plates of segment 8; $(\mathrm{G})$ ventral overview of right 740 sternal plate of segments 10-11, with detail of the penile spines and the elongated, basal, 741 thick cuticular hair of the tergal extensions. Abbreviations: ch, cuticular tuft of hairs; lat, 742 lateral accessory tube; lvs, lateroventral spine; lvt, lateroventral tube; ps, penile spines; 743 sensory spots are marked as closed circles, and glandular cell outlets as dashed circles; numbers after abbreviations indicate the corresponding segment. 

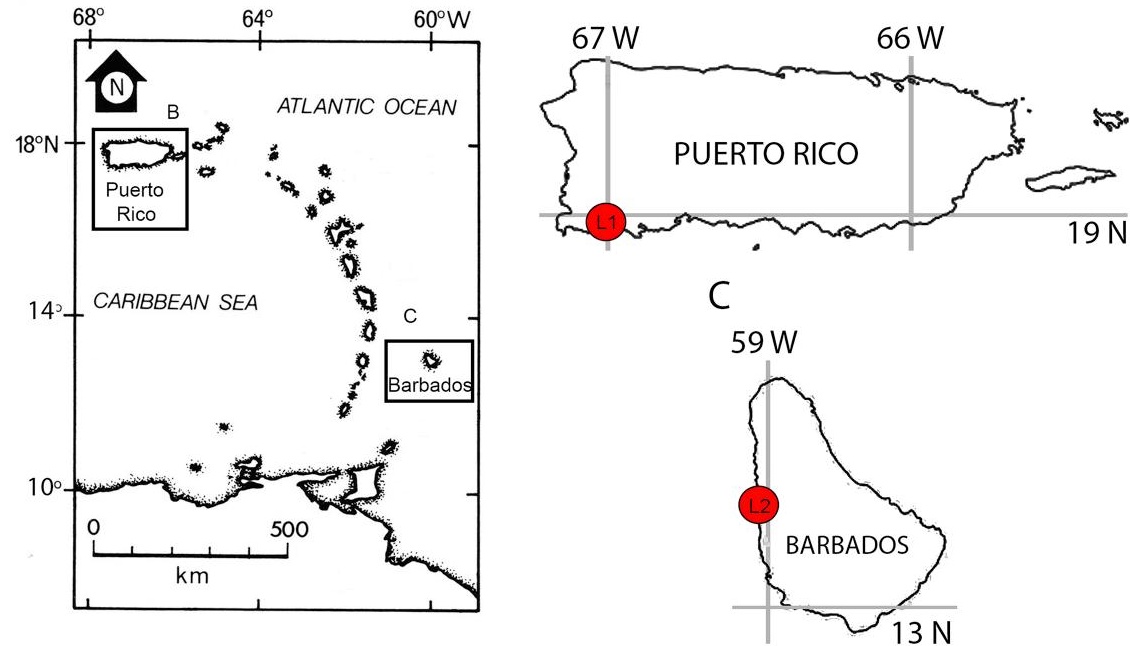

$19 \mathrm{~N}$ 
A

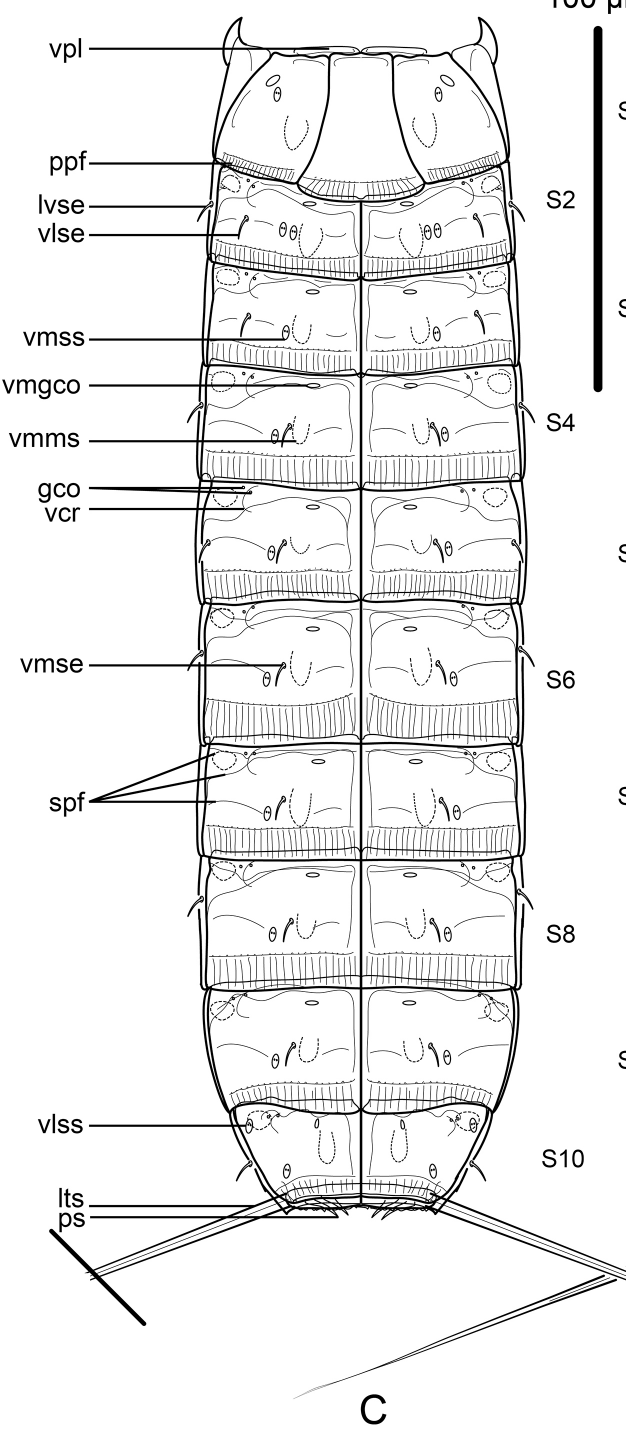

$100 \mu \mathrm{m}$

B

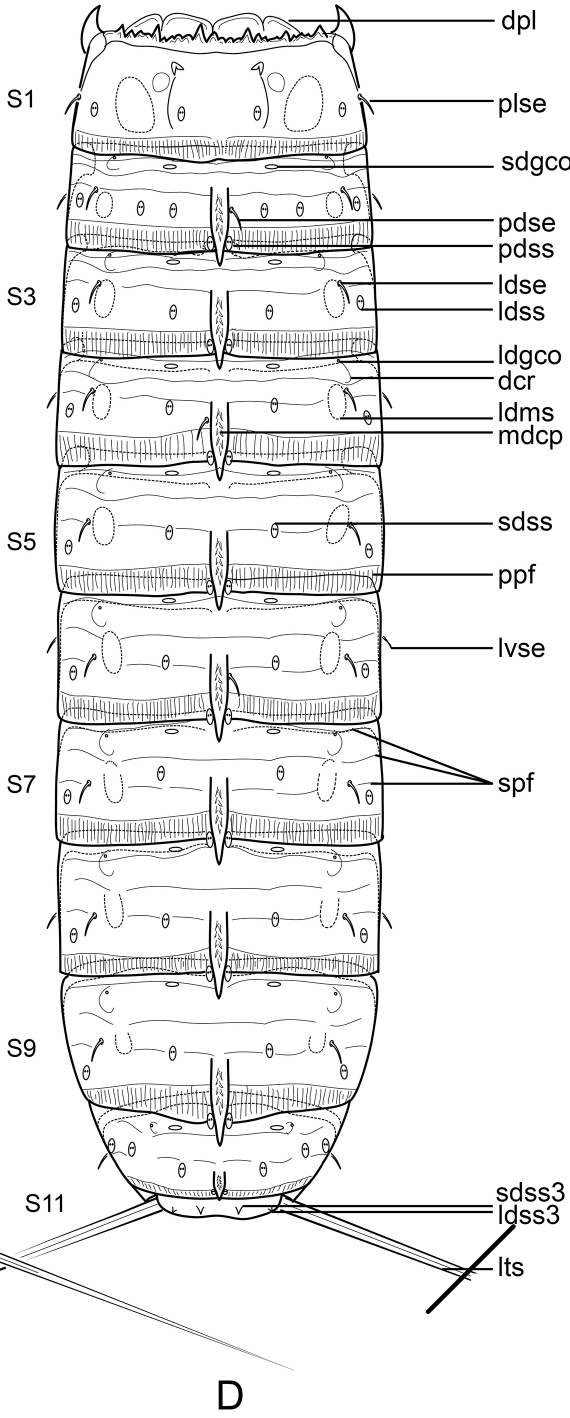




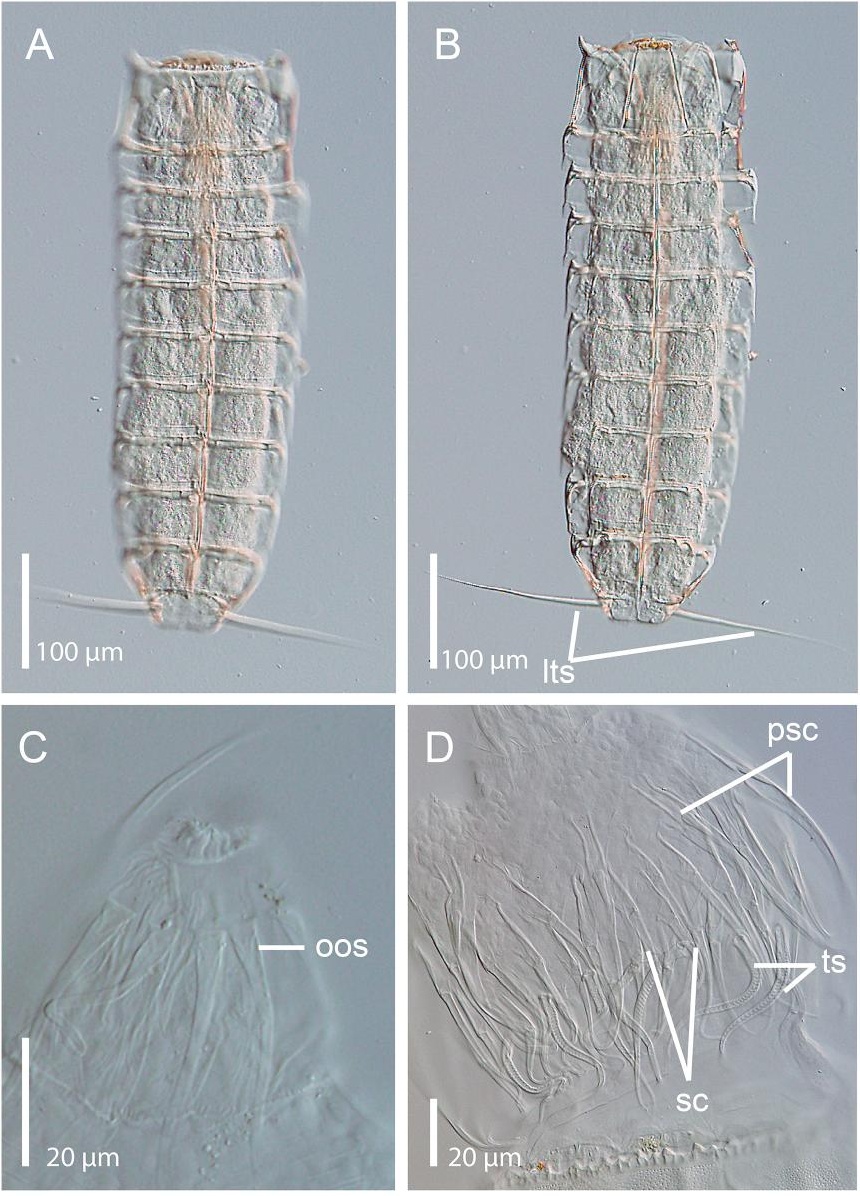

A
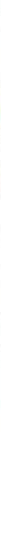


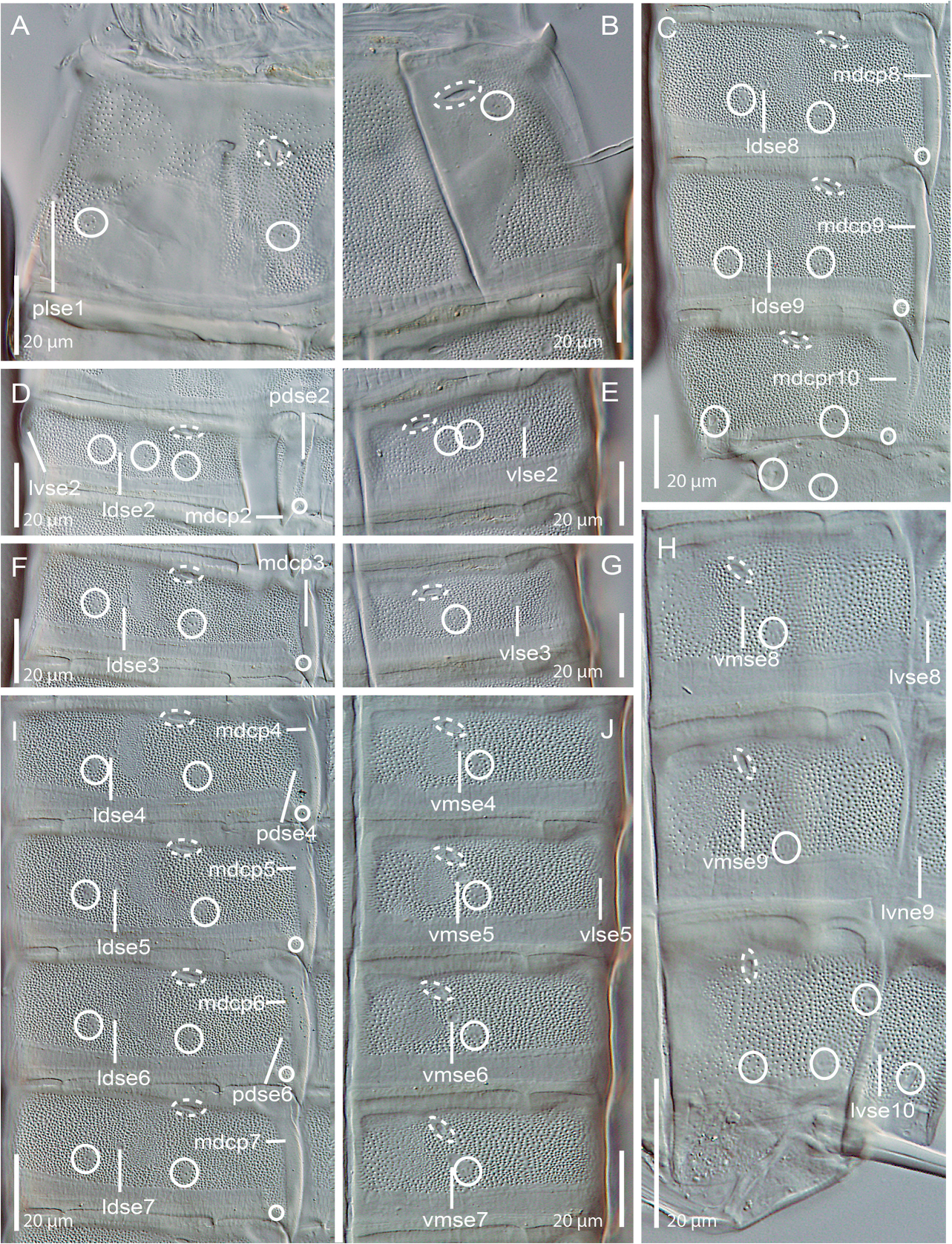




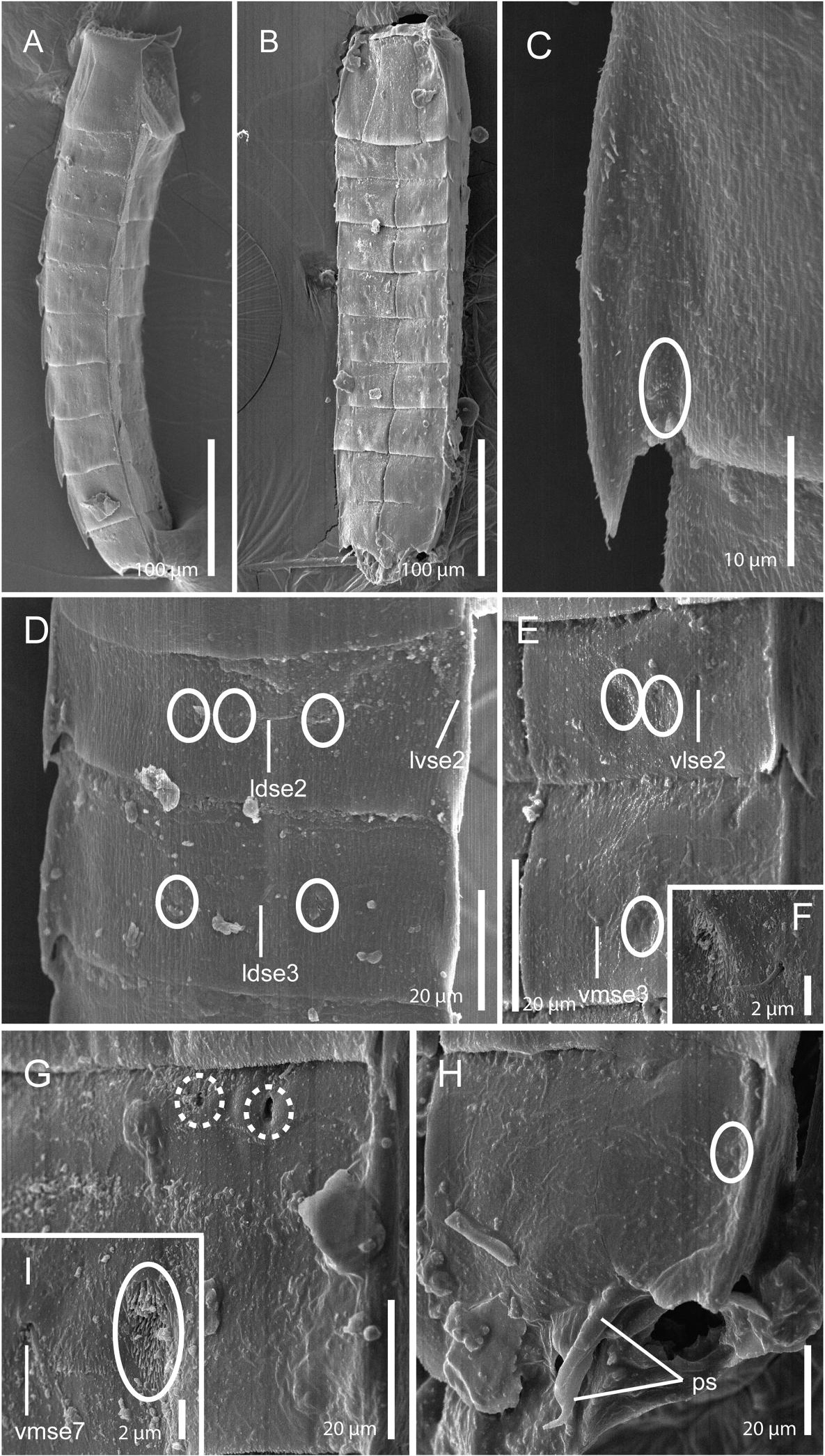


tsp

mvp

vlss
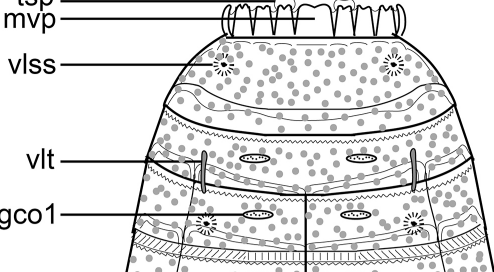

mlgco2

$\therefore$ Fid

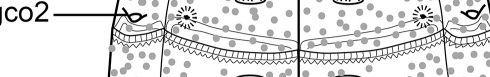

Ivt

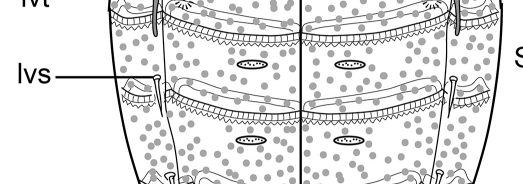

S2

S4

S6

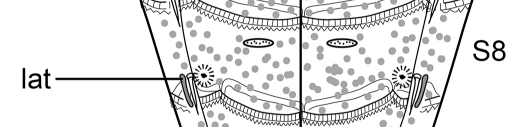

Its

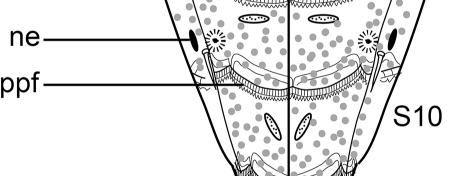

Itas

ch

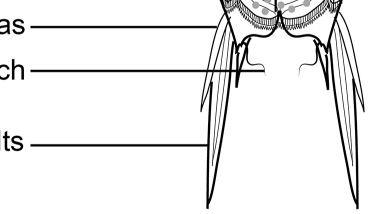

C

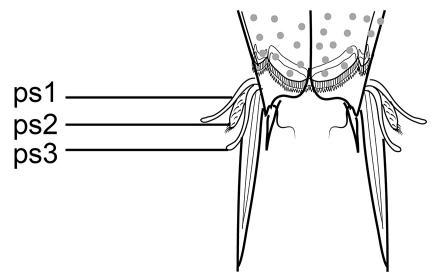

S8
S3

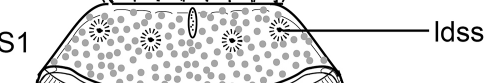

30 - $3 d g c 02$

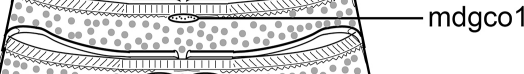

$0 \% 0$.

$\therefore: 8 \%$ pdss

S5

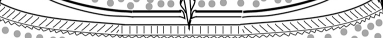

-

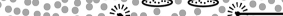

皮 sdss

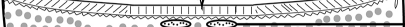

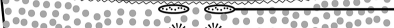

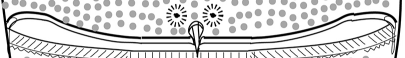

S7

$6 \%$

60:

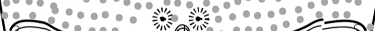
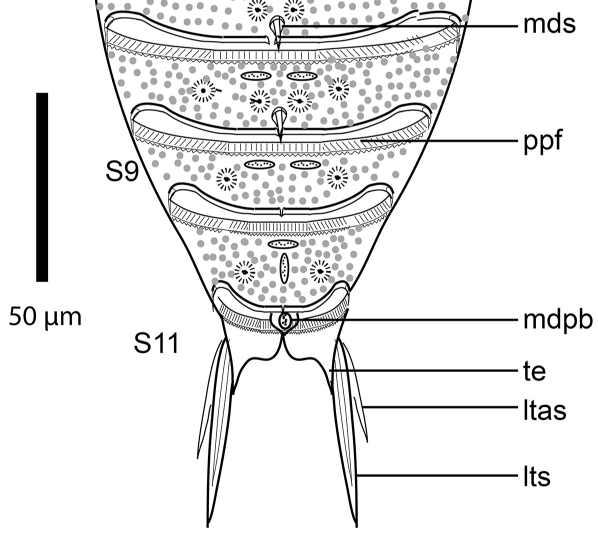

D

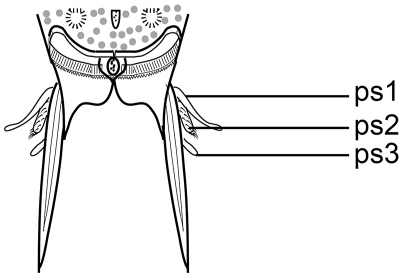




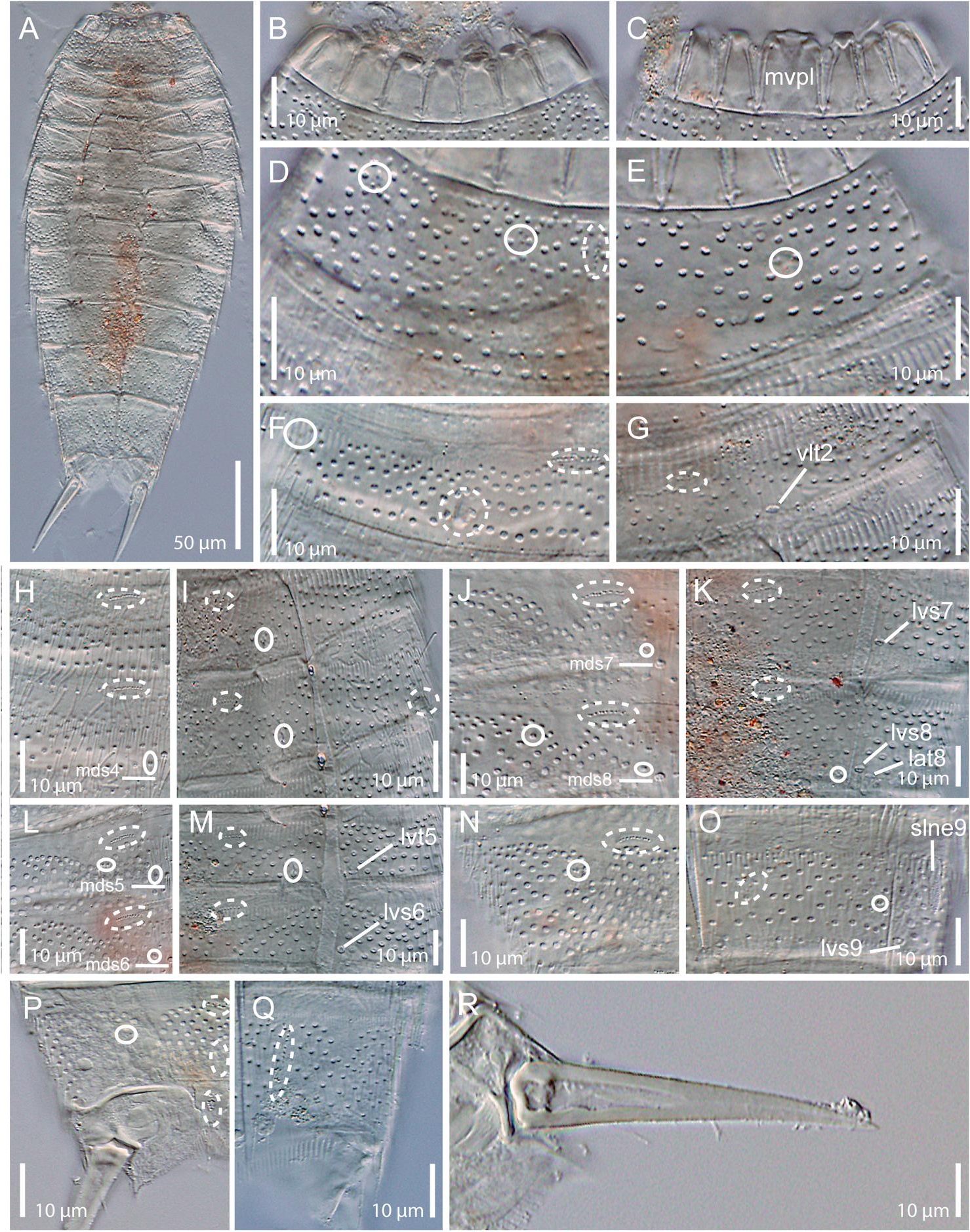




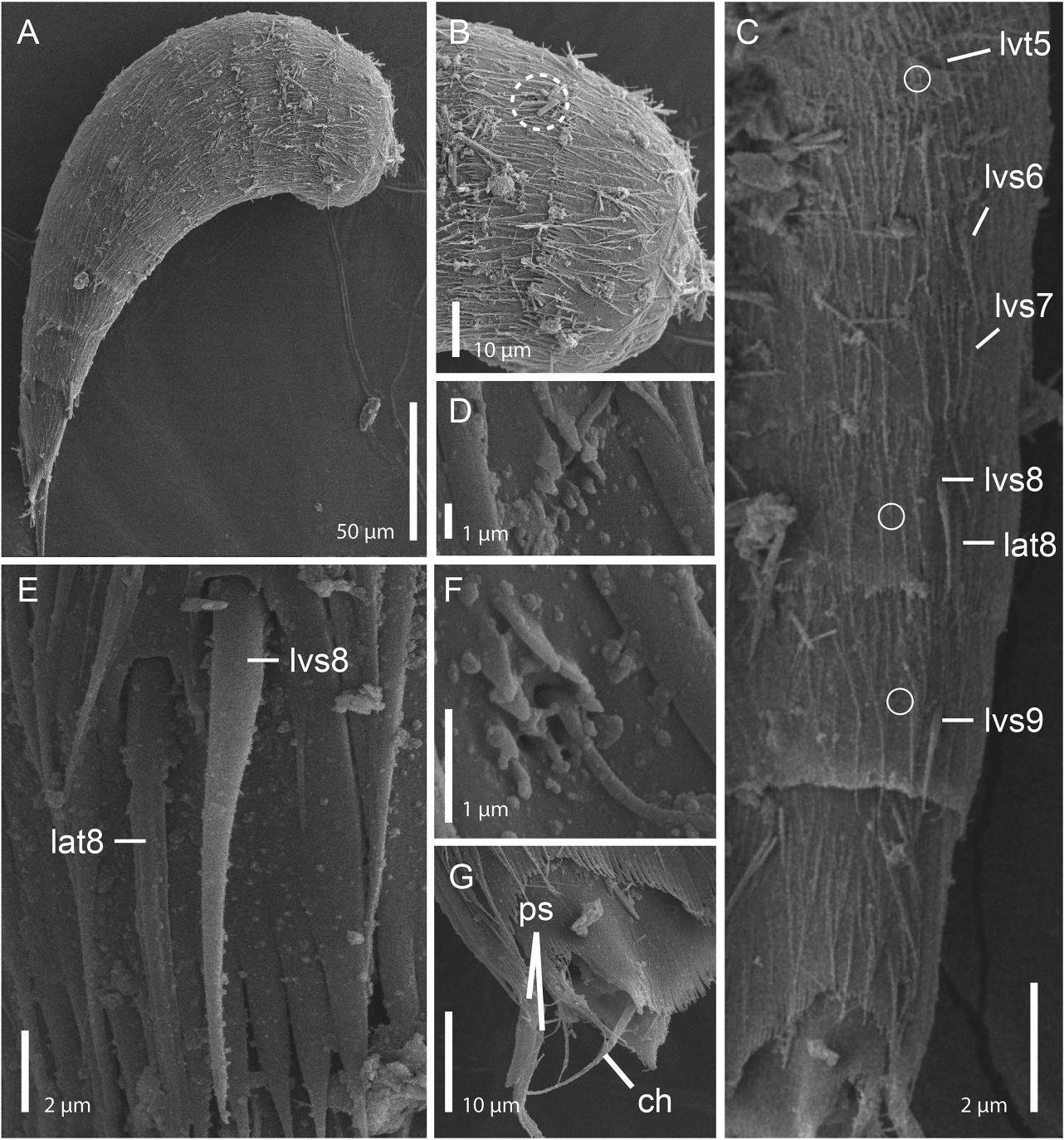

